\section{Romano Santi}

Mariano Croce

Sapienza Università di Roma, Rome, Italy

\section{Introduction}

Santi Romano was born in Palermo, Sicily on January 31, 1875. His origins had a notable impact on his legal training, as Palermo was the cradle of a host of renewed legal studies that changed once and for all the way of approaching public law in Italy. His teacher, Vittorio Emanuele Orlando, was both a leading statesman and an innovator of the notion and practice of public and administrative law. The young Romano contributed to a seminal collection of volumes, edited by Orlando, devoted to Italian administrative law, Primo trattato completo di diritto amministrativo italiano (First Complete Treatise on Italian Administrative Law), published between 1900 and 1915. The importance Orlando and his many collaborators attached to such a monumental scholarly enterprise should not go unnoticed: in his preface to the first volume, Orlando emphasized his and the other contributors' conscious, and eventually successful, attempt at constructing an Italian school of public law. This collection of writings, he claimed, was the necessary counterpoint to the growing expansion of the state's competences in the public realm. While in the past, Italian scholars had been heavily influenced by the
French lawyers who had been working and mulling over the Code Napoléon and, subsequently, by the German pandectists, Orlando insisted that the specialization and evolution of the Italian state called for a full-fledged "homegrown" scholarly apparatus. After obtaining his degree at the University of Palermo, Romano wholeheartedly adhered to this ambitious project.

\section{Overview}

Romano would soon part ways with his mentor (though they remained good friends, with the inevitable ebb and flow of pre- and post-war times) and developed a new, seminal approach to the legal phenomenon. Unlike Orlando, Romano had no penchant for the limelight of politics. He entirely devoted himself to legal studies and legal teaching. He taught in Camerino (1897-1902), Modena (1902-1907), Pisa (1908-1923), and Milan (1924-1928). His unconditional scholarly commitment, however, suffered a serious setback from the 1st of January 1929, when he had to quit his professorship as he was appointed by Benito Mussolini as the President of the Council of State, the court of last resort in administrative matters. Although his judicial activity took most of his time, Romano did not give up his passion for teaching and gave lectures as an Adjunct Professor at the University of Rome "La Sapienza." He first taught Administrative Law, and then moved on to Constitutional Law, as Orlando, who had till 
then held the chair of Constitutional Law at La Sapienza, nominated him as his successor. Romano resigned from the Presidency of the Council of State in 1944, a few months after the Allied Powers liberated Rome from Nazi occupation. Romano died in Rome on November 3, 1947.

However, Romano's quite unexciting life tells us little about the striking path he broke in the history of legal thinking. A unique blend of legal institutionalism and legal pluralism makes his theory one of the most original and certainly topical legal paradigms. It is worth commencing with his notion of institution. In his most famous book, The Legal Order, first published in 1918, he argued that public law theory should get rid of the barren normativism that shored up state-based legal theory. The law can hardly be reduced to a set of norms backed by sanction. The law is neither a norm nor a set of norms. Nor is it reducible to judicial bodies, legal practices and legal procedures. The law comprises all these elements and much more. The law is the theatre in which these elements unfold: it is a process more than a substance. This is why he criticized the pioneer of legal institutionalism, French jurist Maurice Hauriou, as the latter claimed the institution to precede (and produce) the law. There is no diachronic or genetic relation between law and institution. They amount to the same phenomenon. The terms "law," "organization," "institution," and "order" are synonymous with each other. None of them precedes any other. Romano's distinctive argument was that, when it comes to legal theorizing, the term "institution" is a more accurate qualification for the process of organization one that scholars of other disciplines had taken up more seriously than jurists.

More precisely, an institution is the process whereby a group of people stabilize their interactional life with recourse to various techniques: norms, principles, procedures, and others. However, the latter are nothing other than substantive characteristics which can vary, and actually vary, while the phenomenon of organization is the kernel of every institution. If this is the case, then, regardless of the substantive characteristics of this or that order, all interactional contexts that undergo a process of organization are legal orders. Here is the inner link between institutionalism and pluralism. While institutionalization concerns all organized groups, the identity of institution and law qualifies all organized groups as institutions or legal orders. The state is but a contingent form of law with context-specific substantive characteristics determining its shape and structure.

In substance, Romano's refined notion portrays the law as a complex practice by which a group organizes itself as a group. He consistently stuck to this view throughout his intellectual life. In the last text he licensed in 1947, Frammenti di un dizionario giuridico (Fragments of a Legal dictionary), he tackled the question of the function of law. The word "function" conjures a type of "thin functionalism": a social practice meant to order the relations between subjects at various levels of relations and of ordering. Romano's thin functionalism claims the law to be designed to stabilize social practices by establishing a set of powers and authorities - and conversely, all the practices that carry out such a stabilizing function are legal practices. However, he recommended, it is imperative not to separate either conceptually or pragmatically this ordering activity from the entity that is ordered. He dismissed as naïve and untenable the idea that an entity emerges as a factual entity and then gives itself an order by developing a set of legal rules. The law is the embodied organizational form of a sedimented group. At the same time, as Romano unswervingly maintained, it would be a mistake to conclude that in this view legal theory becomes a kind of sociology. The law is not a set of concrete practices, but the particular knowledge that institutions develop to give themselves an organized form. Accordingly, studying the law does not require (at least only) investigating empirical phenomena. It requires eliciting the special knowledge that those phenomena count on to get off the ground and thrive.

From his initial works - in particular, his notable inaugural lecture at the University of Pisa in 1909, devoted to the crisis of the modern state up to Frammenti, Romano was constantly on the lookout for a theory of law that could reconcile pluralism with the need for political order. The 
literature is split between those who think he eventually was a state-centric theorist and those who think he was averse to the existence itself of a common political structure. However, we can see that Romano easily gets away with this facile interpretive bifurcation with his instructive idea of what states are called upon to do. As noted above, the law is an organizational activity that pertains to all groups that need stabilization. While competition and antagonism between legal orders is inevitable, the solution cannon be found in a state-based hierarchy between these orders. Rather, Romano believed that the solution lies is the common legal nature of all orders. This is the reason why he suggested that the custodians of peace and social order are the jurists. Their legal expertise and the knowledge they master provide a negotiation platform for orders to settle their conflicts and govern their coexistence. Certainly, this conception entails a far-reaching revision of the state and its functions. Yet it does not entail its disappearance. The state is a creation of the law, he thought, that makes room for other legal orders that intend to negotiate their peaceful coexistence. Then, it is necessary to (legally) negotiate the effects that orders exert on one another, while any idea of a claimed hierarchy between them is both useless and scientifically unfounded.

\section{Conclusion}

Romano's thinking makes an invaluable contribution to understanding our present. He elaborated on a solid conception of law that makes sense of social transformations at various levels. This conception offers precious insights into the revision of state constitutional orders in a time when legal plurality becomes a main trait of social organization. As the toolkit of modern political theory loses its grip, Romano's legacy on what the law does and how it develops serves as invitation to rethink it as a technique whereby social actors construct semi-autonomous regulations that are to be integrated into the broader body of national and international orders.

\section{Cross-References}

Constitutionalism

- Gierke, Otto von

- Institutional Facts

- Italian Legal Institutionalism

- Legal Institutionalism

\section{References}

Croce M (2018) Whither the state? On Santi Romano's the legal order. Ethics \& Glob Polit 11(2):1-11

Croce M, Salvatore A (2013) The legal theory of Carl Schmitt. Routledge, Abingdon, pp 109-124

de Wilde M (2018) The dark side of institutionalism: Carl Schmitt Reading Santi Romano. Ethics \& Glob Polit $11: 12-24$

Fontanelli F (2011) Santi Romano and L'ordinamento giuridico: the relevance of a forgotten masterpiece for contemporary international, transnational and global legal relations. Transnatl Leg Theory 2(1):67-117

Romano S (1969) Lo Stato moderno e la sua crisi. In: Id., Lo Stato moderno e la sua crisi. Saggi di diritto costituzionale. Giuffrè, Milano, pp 5-26

Romano S (2017) The legal order. Routledge, Abingdon the original Italian version is Romano, S., L'ordinamento giuridico (Firenze: Sansoni, 1946, 2nd revised and enlarged edition)

Romano S (2019) Frammenti di un dizionario giuridico. Macerata, Quodlibet

Salvatore A (2018) A counter-mine that explodes silently: Romano and Schmitt on the Unity of the legal order. Ethics \& Glob Polit 2(1):50-59

Sandulli A (2009) Santi Romano and the perception of the public law complexity. Ital J Public Law 1:1-38

Stone J (1966) Social dimensions of law and justice. Stanford University Press, Stanford, pp 516-528

Vinx L (2018) Santi Romano against the state? Ethics \& Glob Polit 11(2):25-36 